\title{
"Cs-tetra-ferri-annite:" High-pressure and high-temperature behavior of a potential nuclear waste disposal phase
}

\author{
Paola Comodi, Pier Francesco Zanazzi, ${ }^{1}$ ZdeněK Weiss, $^{2}$ Milan Rieder,, ${ }^{3, *}$ \\ and Milan DrábeK ${ }^{4}$
}

\author{
'Dipartimento di Scienze della Terra, Università di Perugia, Piazza Università, I-06100 Perugia, Italy \\ ${ }^{2}$ Central Analytical Laboratory, Technical University Ostrava, CZ-70833 Ostrava-Poruba, Czech Republic \\ ${ }^{3}$ Institute of Geochemistry, Mineralogy and Mineral Resources, Charles University, Albertov 6, \\ CZ-12843 Praha 2, Czech Republic \\ ${ }^{4}$ Czech Geological Survey, Geologická 6, CZ-15200 Praha 6, Czech Republic
}

\begin{abstract}
Structure deformations induced by pressure and temperature in synthetic "Cs-tetra-ferriannite" $1 \mathrm{M}\left[\mathrm{Cs}_{1.78}\left(\mathrm{Fe}^{2+}{ }_{5.93} \mathrm{Fe}^{3+}{ }_{0.07}\right)\left(\mathrm{Si}_{6.15} \mathrm{Fe}^{3+}{ }_{1.80} \mathrm{Al}_{0.05}\right) \mathrm{O}_{20}(\mathrm{OH})_{4}\right]$, space group $C 2 / m$, were analyzed to investigate the capability of the mica structure to store the radiogenic isotopes ${ }^{135} \mathrm{Cs}$ and ${ }^{137} \mathrm{Cs}$. "Cs-tetra-ferri-annite" is not a mineral name, but for the sake of brevity is used here to designate a synthetic analog of the mineral tetra-ferri-annite. The bulk modulus and its pressure derivative determined by fitting the unit-cell volumes between 0 and $47 \mathrm{kbar}$ to a third-order Birch-Murnaghan equation of state are $\mathrm{K}_{0}=257(8) \mathrm{kbar}$ and $\mathrm{K}_{0}{ }^{\prime}=21(1)$, respectively. Between $23{ }^{\circ} \mathrm{C}$ and $582{ }^{\circ} \mathrm{C}$, the $a$ and $b$ lattice parameters remain essentially unchanged, but the thermal expansion coefficient of the $\mathbf{c}$ axis is $\alpha_{\mathbf{c}}=3.12(9)$ $\times 10^{-5}{ }^{\circ} \mathrm{C}^{-1}$. High pressure $(P)$ and high temperature $(T)$ produce limited internal strain in the structure. The tetrahedral rotation angle, $\alpha$, is very small and does not change significantly throughout the $P$ and $T$ range investigated. Above $450{ }^{\circ} \mathrm{C}$ in air, "Cs-tetraferri-annite" underwent an oxidation of octahedral iron in the M2cis site, balanced by the loss of $\mathrm{H}$ and shown by a decrease of the unit-cell volume.

Independent isobaric data on thermal expansion and isothermal compressibility data define the "geometric" equation of state for "Cs-tetra-ferri-annite": $V / V_{0}=1+3.0(1)$ $10^{-5} T-2.68(9) 10^{-3} P+2.0(2) \times 10^{-5} P^{2}$ where $T$ is in degrees Celsius, $P$ is in kilobars. The $\alpha / \beta$ ratio of about $12 \mathrm{bar} /{ }^{\circ} \mathrm{C}$ indicate that the cell volume of "Cs-tetra-ferri-annite" remains unchanged under geothermal gradients of $\sim 23{ }^{\circ} \mathrm{C} / \mathrm{km}$. On the whole, the data confirm that the structure of "Cs-tetra-ferri-annite" may be a suitable candidate for the storage of large ions, such as Cs in the interlayer and should be considered as a potential Synroc component.
\end{abstract}

\section{INTRODUCTION}

The storage of high-level radioactive waste is a liability of nuclear technologies (Lewis 1985). Potential containers for fission products are mineral-like phases capable of including several radioisotopes in their structure, mostly as dilute solid solutions. They must have long-term stability and resistance to radiation damage and to chemical, physical, and mechanical agents. One such ceramic material with a simple manufacturing technology is "Synroc," a multiphase immobilizing barrier based on geochemical principles (Ringwood 1985), which consists mainly of rutile, zirconolite, perovskite, and hollandite. Of these, hollandite can trap ${ }^{135} \mathrm{Cs}$ and ${ }^{137} \mathrm{Cs}$, which are among the most problematic radiogenic isotopes because of their large ionic radius, strong activity, and medium half-life.

*E-mail: Rieder@mbox.Cesnet.Cz
The recently synthesized one-layer mica "Cs-tetra-ferri-annite" was proposed as another promising candidate for the storage of radiogenic Cs isotopes (Mellini et al. 1996). "Cs-tetra-ferri-annite" was easily synthesized under hydrothermal conditions and the data available indicate it is a mica structure with limited internal strain, likely to have strong thermal stability. In this context, the structural response of Cs-mica to elevated pressure and elevated temperature should be known.

This study determines the compressibility of "Cs-tetra-ferri-annite" and its thermal expansion. Its structure was refined at a set of temperatures and pressures. The results are compared with those for phlogopite (Hazen and Finger 1978) and dioctahedral $\mathrm{K}$ and $\mathrm{Na}$ micas (Comodi and Zanazzi 1995; 1997) to elucidate the role of the interlayer cation in the mica under elevated $T$ and $P$. 
TABLE 1. Conditions of data collection and refinement of the structure of "Cs-tetra-ferri-annite"

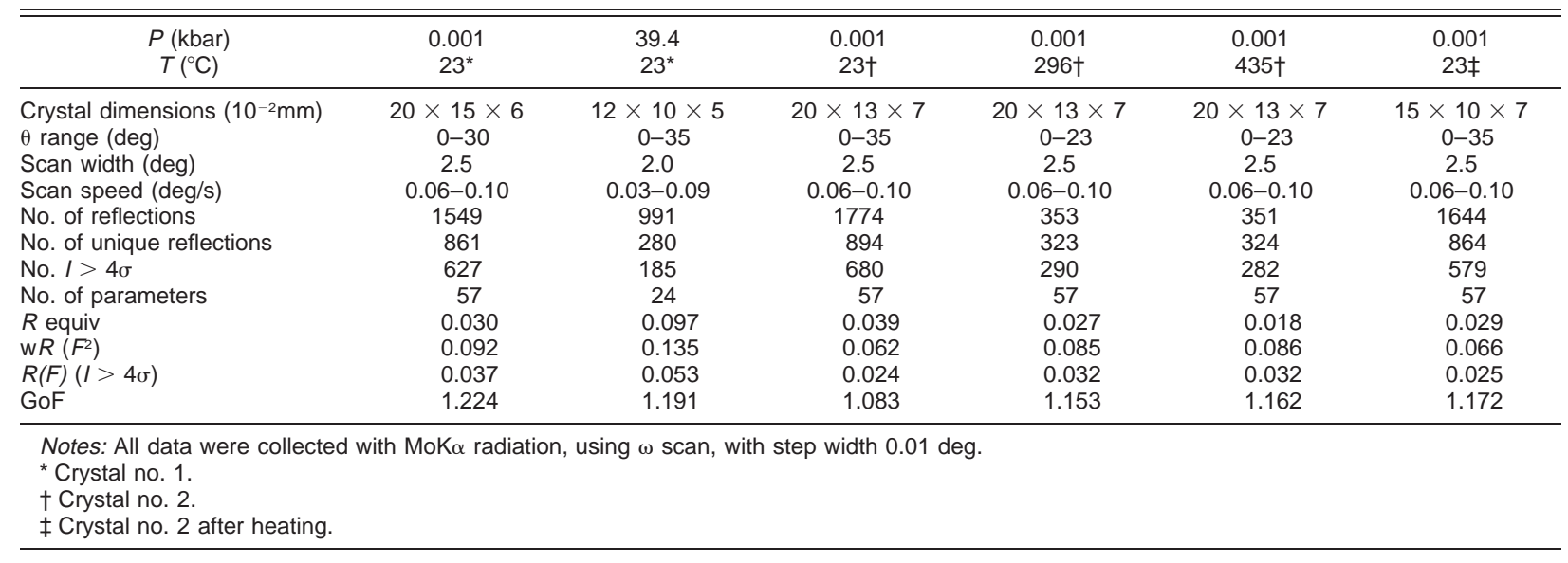

\section{EXPERIMENTAL METHODS}

The sample of "Cs-tetra-ferri-annite" was synthesized under hydrothermal conditions at $550^{\circ} \mathrm{C}$ and 1 kbar (Drábek et al. 1998). The crystals used for diffraction experiments came from the same run as those studied by Mellini et al. (1996). Their composition is $\mathrm{Cs}_{1.78}\left(\mathrm{Fe}_{5.93}^{2+} \mathrm{Fe}_{0.07}^{3+}\right)$ $\left(\mathrm{Si}_{6.15} \mathrm{Fe}_{1.80}^{3+} \mathrm{Al}_{0.05}\right) \mathrm{O}_{20}(\mathrm{OH})_{4}$; the polytype is $1 \mathrm{M}$.

Diffraction data were collected on a four-circle Philips PW1100 diffractometer using graphite monochromati-

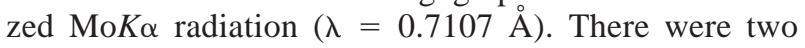
sets of data for high $P$ (crystal no. 1) and high $T$ (crystal no. 2) experiments. Integrated intensities from two equivalent reciprocal lattice quadrants with indices \pm $h k l$ and $\pm h \bar{k} l$ were collected for structural refinement at room conditions. Data were corrected for absorption according to the method of North et al. (1968) and merged. Starting from the atomic parameters of Mellini et al. (1996), anisotropic refinement in space group $C 2 / m$ was carried out using the SHELXL93 program (Sheldrick 1993). Neutral atomic scattering factor values from the International Tables for X-ray Crystallography (Ibers and Hamilton 1974) were used. Details of the refinement and data collection are in Table 1. Final atomic coordinates and displacement parameters are in Table 2; observed and calculated structure factors are in Table $3 .{ }^{1}$

\section{High- $P$ experiments}

A Merrill-Bassett diamond-anvil cell (DAC) with 1/8 carat diamonds was used for the high-pressure study. A $\mathrm{Sm}^{2+}: \mathrm{BaFCl}$ powder was used for pressure calibration (Comodi and Zanazzi 1993a), and a 4:1 methanol:ethanol mixture served as pressure-transmitting medium. Pressure was monitored by measuring the wavelength shift of $\mathrm{Sm}^{2+}$ line excited by a $100 \mathrm{~mW}$ argon laser and detected

\footnotetext{
${ }^{1}$ For a copy of Table 3, document item AM-98-006, contact the Business Office of the Mineralogical Society of America (see inside front cover of recent issue) for price information. Deposit items may also be available on the American Mineralogist web site at http://www.minsocam.org.
}

by a $100 \mathrm{~cm}$ Jarrell-Ash optical spectrometer. The precision of the pressure measurements was $\pm 0.5 \mathrm{kbar}$. Steel foil $250 \mu \mathrm{m}$ thick with a hole $300 \mu \mathrm{m}$ in diameter was used as gasket material. Lattice parameters were determined at pressures between 0.001 and $47 \mathrm{kbar}$ (Table 4) by applying the least-squares method to diffraction angles of about 30 selected reflections.

Intensity data at $39.4 \mathrm{kbar}$ were collected up to $35^{\circ} \theta$, adopting the non-bisecting geometry (Denner et al. 1978) and the $2{ }^{\circ} \omega$ scan mode; the data were corrected for pressure-cell absorption by an experimental attenuation curve (Finger and King 1978) and analyzed with a digital procedure (Comodi et al. 1994), visually inspected to eliminate errors due to the overlap of diffraction effects from various parts of the diamond cell or by shadowing by the gasket, and merged to an independent data set. The structure was refined with individual isotropic atomic displacement parameters using the SHELXL93 program.

\section{High- $T$ experiments}

For the high-temperature study, a microfurnace constructed at the University of Perugia and described by Comodi and Zanazzi (1993b) was used. The temperature of the heating device was calibrated by thermal expansion of a NaCl crystal (Pathak and Vasavada 1970). Crystal no. 2 was fixed in a silica capillary with a ceramic cement (M-Bond GA-100 cement, M-M Division, Measurements Group Inc., Raleigh, North Carolina, U.S.A.). To monitor temperature, an $\mathrm{NaCl}$ single crystal was mounted on the capillary, and its lattice parameter $a$ was determined at each temperature from the $\theta$ angles of 32 selected reflections. The precision of temperature measurements was better than $\pm 5{ }^{\circ} \mathrm{C}$. Two hours were allowed for thermal equilibration at each temperature. Intensities used for structure refinements were measured at 296 and $435{ }^{\circ} \mathrm{C}$ (Table 1). For the SHELXL93 refinement, anisotropic atomic displacement parameters were used for all atoms.

Lattice parameters of the mica were measured in air at several temperatures between 23 and $582{ }^{\circ} \mathrm{C}$ (Table 5). 
TABLE 2. Fractional atomic coordinates and displacement factors $\left(\AA^{2}\right)$ for "Cs-tetra-ferri-annite"

\begin{tabular}{|c|c|c|c|c|}
\hline Atom & $x / a$ & $y / b$ & $z / c$ & $U$ or $U_{\text {eq }}$ \\
\hline Cs & 0 & $1 / 2$ & 0 & $0.0221(4)$ \\
\hline Cs & 0 & $1 / 2$ & 0 & $0.0165(7)$ \\
\hline Cs & 0 & $1 / 2$ & 0 & $0.0209(2)$ \\
\hline Cs & 0 & $1 / 2$ & 0 & $0.0410(7)$ \\
\hline Cs & 0 & $1 / 2$ & 0 & $0.0495(8)$ \\
\hline Cs & 0 & $1 / 2$ & 0 & $0.0243(2)$ \\
\hline M1 & 0 & 0 & $1 / 2$ & $0.0110(5)$ \\
\hline M1 & 0 & 0 & $1 / 2$ & $0.010(1)$ \\
\hline M1 & 0 & 0 & $1 / 2$ & $0.0088(2)$ \\
\hline M1 & 0 & 0 & $1 / 2$ & $0.0195(9)$ \\
\hline M1 & 0 & 0 & $1 / 2$ & $0.0251(9)$ \\
\hline M1 & 0 & 0 & $1 / 2$ & $0.0148(3)$ \\
\hline M2 & 0 & $0.3323(2)$ & $1 / 2$ & $0.0099(4)$ \\
\hline M2 & 0 & $0.3327(3)$ & $1 / 2$ & $0.0099(8)$ \\
\hline $\mathrm{M} 2$ & 0 & $0.33192(6)$ & $1 / 2$ & $0.0090(2)$ \\
\hline M2 & 0 & $0.3319(2)$ & $1 / 2$ & $0.0202(8)$ \\
\hline M2 & 0 & $0.3326(2)$ & $1 / 2$ & $0.0249(8)$ \\
\hline M2 & 0 & $0.3393(1)$ & $1 / 2$ & $0.0151(3)$ \\
\hline $\mathrm{T}$ & $0.0797(3)$ & $0.1666(2)$ & $0.2384(1)$ & $0.0111(5)$ \\
\hline $\mathrm{T}$ & $0.0753(7)$ & $0.1666(3)$ & $0.2252(13)$ & $0.0121(9)$ \\
\hline $\mathrm{T}$ & $0.0796(1)$ & $0.16662(7)$ & $0.23820(6)$ & $0.0099(2)$ \\
\hline $\mathrm{T}$ & $0.0793(3)$ & $0.1662(2)$ & $0.2393(2)$ & $0.0184(9)$ \\
\hline $\mathrm{T}$ & $0.0793(3)$ & $0.1667(2)$ & $0.2398(2)$ & $0.0229(9)$ \\
\hline $\mathrm{T}$ & $0.0797(2)$ & $0.1677(1)$ & $0.2367(1)$ & $0.0142(3)$ \\
\hline O1 & $0.0588(17)$ & 0 & $0.1836(8)$ & $0.029(2)$ \\
\hline 01 & $0.061(4)$ & 0 & $0.173(6)$ & $0.034(5)$ \\
\hline O1 & $0.0610(7)$ & 0 & $0.1838(3)$ & $0.0272(8)$ \\
\hline 01 & $0.0615(17)$ & 0 & $0.1849(7)$ & $0.042(2)$ \\
\hline 01 & $0.0633(18)$ & 0 & $0.1870(8)$ & $0.052(3)$ \\
\hline O1 & $0.0588(10)$ & 0 & $0.1843(5)$ & $0.032(1)$ \\
\hline $\mathrm{O} 2$ & $0.3117(11)$ & $0.2496(7)$ & $0.1824(5)$ & $0.029(1)$ \\
\hline $\mathrm{O} 2$ & $0.306(3)$ & $0.249(2)$ & $0.169(4)$ & $0.030(3)$ \\
\hline $\mathrm{O} 2$ & $0.3119(5)$ & $0.2501(3)$ & $0.1844(2)$ & $0.0287(6)$ \\
\hline $\mathrm{O} 2$ & $0.3146(11)$ & $0.2503(7)$ & $0.1864(5)$ & $0.041(2)$ \\
\hline $\mathrm{O} 2$ & $0.3128(11)$ & $0.2512(7)$ & $0.1865(5)$ & $0.047(2)$ \\
\hline $\mathrm{O} 2$ & $0.3130(7)$ & $0.2483(5)$ & $0.1812(3)$ & $0.0324(9)$ \\
\hline $\mathrm{O} 3$ & $0.1325(8)$ & $0.1664(5)$ & $0.3958(4)$ & $0.0123(9)$ \\
\hline $\mathrm{O} 3$ & $0.131(2)$ & $0.167(1)$ & $0.394(4)$ & $0.015(3)$ \\
\hline $\mathrm{O} 3$ & $0.1326(3)$ & $0.1662(2)$ & $0.3962(2)$ & $0.0118(4)$ \\
\hline O3 & $0.1325(9)$ & $0.1667(5)$ & $0.3965(5)$ & $0.021(2)$ \\
\hline $\mathrm{O} 3$ & $0.1303(9)$ & $0.1672(5)$ & $0.3961(5)$ & $0.024(2)$ \\
\hline O3 & $0.1337(5)$ & $0.1719(3)$ & $0.3961(3)$ & $0.0161(6)$ \\
\hline O4 & $0.1322(12)$ & $1 / 2$ & $0.4018(7)$ & $0.012(1)$ \\
\hline $\mathrm{O} 4$ & $0.131(3)$ & $1 / 2$ & $0.392(4)$ & $0.010(3)$ \\
\hline $\mathrm{O} 4$ & $0.1325(5)$ & $1 / 2$ & $0.4015(3)$ & $0.0115(6)$ \\
\hline O4 & $0.1325(14)$ & $1 / 2$ & $0.4008(8)$ & $0.025(2)$ \\
\hline O4 & $0.1348(14)$ & $1 / 2$ & $0.4016(8)$ & $0.030(2)$ \\
\hline $\mathrm{O} 4$ & $0.1373(8)$ & $1 / 2$ & $0.4059(4)$ & $0.0166(9)$ \\
\hline
\end{tabular}

Note: For each atom, the six values from top to bottom correspond to crystal no. 1 (0.001 and 39.4 kbar), crystal no. $2\left(23^{\circ} \mathrm{C}, 296{ }^{\circ} \mathrm{C}, 435^{\circ} \mathrm{C}\right.$ and $23{ }^{\circ} \mathrm{C}$ after heating). Estimated standard deviations (in parentheses) refer to the last digit.

Above $450{ }^{\circ} \mathrm{C}$, the cell volume increased at a decidedly lesser rate, most probably due to oxidation of octahedral $\mathrm{Fe}^{2+}$ to $\mathrm{Fe}^{3+}$ and the related loss of hydrogen with a concomitant decrease of volume. The sample was then kept at $582{ }^{\circ} \mathrm{C}$, and its lattice parameters were measured at regular time intervals (Table 6). During the first $30 \mathrm{~h}$, unit-cell volume continuously decreased without significant variation of the reflection intensities. Subsequently, a progressive decrease of the intensities was observed. This indicated more serious damage of the structure and, therefore, after $\sim 50 \mathrm{~h}$, the temperature was allowed to decrease. The drop of the unit-cell volume was irreversible.

After reaching room temperature, a fragment of crystal
TABLE 4. Lattice parameters of "Cs-tetra-ferri-annite" (crystal no. 1) at pressure

\begin{tabular}{lccccc}
\hline \hline$P$ (kbar) & $a(\AA)$ & $b(\AA)$ & $c(\AA)$ & $\beta\left(^{\circ}\right)$ & $V\left(\AA^{3}\right)$ \\
\hline 0.001 & $5.486(1)$ & $9.506(1)$ & $10.818(1)$ & $99.67(6)$ & $556.1(1)$ \\
3.4 & $5.477(3)$ & $9.490(2)$ & $10.735(2)$ & $99.7(2)$ & $549.9(4)$ \\
8.2 & $5.474(2)$ & $9.481(6)$ & $10.626(2)$ & $99.9(4)$ & $543.3(6)$ \\
13.2 & $5.467(3)$ & $9.469(2)$ & $10.526(4)$ & $100.0(2)$ & $536.5(4)$ \\
17.9 & $5.446(4)$ & $9.474(2)$ & $10.452(8)$ & $100.0(3)$ & $533.0(5)$ \\
27.1 & $5.459(2)$ & $9.455(2)$ & $10.306(2)$ & $100.2(2)$ & $523.6(3)$ \\
28.4 & $5.458(2)$ & $9.451(4)$ & $10.299(2)$ & $100.2(2)$ & $522.8(4)$ \\
29.7 & $5.457(2)$ & $9.450(3)$ & $10.277(6)$ & $100.2(5)$ & $521.5(4)$ \\
30.7 & $5.452(2)$ & $9.440(2)$ & $10.264(2)$ & $100.1(2)$ & $520.1(3)$ \\
31.6 & $5.453(2)$ & $9.443(4)$ & $10.259(2)$ & $100.3(7)$ & $519.8(4)$ \\
34.3 & $5.447(2)$ & $9.435(2)$ & $10.214(5)$ & $100.3(3)$ & $516.5(4)$ \\
36.5 & $5.446(2)$ & $9.434(4)$ & $10.185(4)$ & $100.4(3)$ & $514.8(7)$ \\
38.1 & $5.447(2)$ & $9.442(3)$ & $10.178(9)$ & $100.3(4)$ & $515.1(8)$ \\
38.2 & $5.446(4)$ & $9.432(2)$ & $10.172(4)$ & $100.3(4)$ & $514.0(5)$ \\
38.6 & $5.441(4)$ & $9.435(3)$ & $10.172(2)$ & $100.3(4)$ & $513.9(4)$ \\
39.4 & $5.444(3)$ & $9.439(3)$ & $10.185(4)$ & $100.2(4)$ & $515.1(6)$ \\
42.9 & $5.450(2)$ & $9.438(2)$ & $10.129(5)$ & $100.3(5)$ & $512.6(4)$ \\
47.0 & $5.439(2)$ & $9.423(2)$ & $10.116(2)$ & $100.4(2)$ & $510.0(3)$ \\
\hline
\end{tabular}

no. 2 was recovered from the capillary and mounted for intensity collection in air to study structural changes induced by heating. The quality of the fragment was sufficient to allow structural refinement.

\section{Results}

\section{Ambient conditions}

The results of the anisotropic structural refinements of synthetic "Cs-tetra-ferri-annite" at room conditions are in close agreement with those of Mellini et al. (1996). Relevant bond lengths and geometrical parameters of the 2:1 layer and the interlayer region are listed in Tables 7 and 8 .

The structure is homooctahedral, with the M1 and M2 octahedra occupied by divalent iron (Ďurovič 1981). The mean Fe-O bond lengths are 2.130 and $2.126 \AA$, respectively, somewhat larger than the 2.121 and $2.101 \mathrm{~A}$ reported in annite (Hazen and Burnham 1973); however, the latter exhibits a partial ordering of $\mathrm{Fe}^{3+}$, Ti, and $\mathrm{Mn}$ in the M2 site. The mean T-O distance in "Cs-tetra-ferri-

TABLE 5. Lattice parameters of "Cs-tetra-ferri-annite" (crystal no. 2) at temperature

\begin{tabular}{rccccc}
\hline \hline$T\left({ }^{\circ} \mathrm{C}\right)$ & $a(\AA)$ & $b(\AA)$ & $c(\AA)$ & $\beta\left({ }^{\circ}\right)$ & $V\left(\AA^{3}\right)$ \\
\hline 23 & $5.480(2)$ & $9.498(2)$ & $10.820(2)$ & $99.76(6)$ & $555.0(3)$ \\
58 & $5.479(2)$ & $9.507(3)$ & $10.829(3)$ & $99.67(6)$ & $556.1(5)$ \\
118 & $5.479(2)$ & $9.504(3)$ & $10.843(3)$ & $99.70(6)$ & $556.6(5)$ \\
167 & $5.477(2)$ & $9.504(3)$ & $10.864(3)$ & $99.66(6)$ & $557.4(5)$ \\
179 & $5.479(2)$ & $9.502(3)$ & $10.865(3)$ & $99.64(6)$ & $557.7(5)$ \\
228 & $5.479(2)$ & $9.497(3)$ & $10.891(3)$ & $99.64(6)$ & $558.7(5)$ \\
238 & $5.478(2)$ & $9.501(3)$ & $10.886(3)$ & $99.58(6)$ & $558.7(5)$ \\
266 & $5.474(2)$ & $9.500(3)$ & $10.886(3)$ & $99.58(6)$ & $558.2(5)$ \\
296 & $5.480(2)$ & $9.500(3)$ & $10.907(3)$ & $99.60(6)$ & $559.9(5)$ \\
319 & $5.476(2)$ & $9.500(3)$ & $10.914(3)$ & $99.61(6)$ & $559.9(5)$ \\
360 & $5.477(2)$ & $9.502(3)$ & $10.933(3)$ & $99.60(6)$ & $561.0(5)$ \\
394 & $5.477(2)$ & $9.501(3)$ & $10.945(3)$ & $99.58(6)$ & $561.6(5)$ \\
421 & $5.479(2)$ & $9.497(3)$ & $10.948(3)$ & $99.59(6)$ & $561.7(5)$ \\
435 & $5.476(2)$ & $9.502(3)$ & $10.954(3)$ & $99.54(6)$ & $562.1(5)$ \\
496 & $5.475(2)$ & $9.498(3)$ & $10.970(3)$ & $99.55(6)$ & $562.6(5)$ \\
582 & $5.482(2)$ & $9.499(3)$ & $11.005(3)$ & $99.53(6)$ & $565.2(5)$ \\
23 & $5.452(2)$ & $9.448(3)$ & $10.786(3)$ & $99.77(6)$ & $547.5(5)$ \\
\hline
\end{tabular}


TABLE 6. Time dependence of lattice parameters of "Cs-tetraferri-annite" (crystal no. 2) at $582{ }^{\circ} \mathrm{C}$

\begin{tabular}{rccccc}
\hline \hline $\begin{array}{r}\text { Time } \\
(\mathrm{min})\end{array}$ & $a(\AA)$ & $b(\AA)$ & $c(\AA)$ & $\beta\left({ }^{\circ}\right)$ & $V\left(\AA^{3}\right)$ \\
\hline 0 & $5.482(2)$ & $9.499(3)$ & $11.005(3)$ & $99.53(6)$ & $565.2(5)$ \\
30 & $5.482(2)$ & $9.499(3)$ & $11.000(3)$ & $99.51(6)$ & $564.9(5)$ \\
45 & $5.480(2)$ & $9.497(3)$ & $10.992(3)$ & $99.55(6)$ & $564.1(5)$ \\
75 & $5.475(2)$ & $9.496(3)$ & $10.995(3)$ & $99.50(6)$ & $563.8(5)$ \\
105 & $5.479(2)$ & $9.493(3)$ & $10.995(3)$ & $99.50(6)$ & $564.1(5)$ \\
135 & $5.477(2)$ & $9.495(3)$ & $10.988(3)$ & $99.54(6)$ & $563.5(5)$ \\
165 & $5.474(2)$ & $9.492(3)$ & $10.994(3)$ & $99.50(6)$ & $563.4(5)$ \\
295 & $5.474(2)$ & $9.488(3)$ & $10.985(3)$ & $99.48(6)$ & $562.7(5)$ \\
355 & $5.475(2)$ & $9.488(3)$ & $10.984(3)$ & $99.56(6)$ & $562.7(5)$ \\
450 & $5.470(2)$ & $9.486(3)$ & $10.986(3)$ & $99.52(6)$ & $562.2(5)$ \\
525 & $5.472(2)$ & $9.479(3)$ & $10.984(3)$ & $99.53(6)$ & $561.8(5)$ \\
1305 & $5.466(2)$ & $9.476(3)$ & $10.976(3)$ & $99.51(6)$ & $560.7(5)$ \\
1800 & $5.465(2)$ & $9.467(3)$ & $10.972(3)$ & $99.50(6)$ & $559.9(5)$ \\
2865 & $5.461(2)$ & $9.463(3)$ & $10.955(3)$ & $99.49(6)$ & $558.3(5)$ \\
2915 & $5.461(2)$ & $9.463(3)$ & $10.956(3)$ & $99.47(6)$ & $558.4(5)$ \\
3165 & $5.460(2)$ & $9.460(3)$ & $10.957(3)$ & $99.48(6)$ & $558.2(5)$ \\
3180 & $5.456(2)$ & $9.457(3)$ & $10.960(3)$ & $99.49(6)$ & $557.8(5)$ \\
3285 & $5.458(2)$ & $9.457(3)$ & $10.955(3)$ & $99.54(6)$ & $557.6(5)$ \\
\hline
\end{tabular}

annite" is $1.686 \AA$, as expected if about $1 / 4$ of tetrahedral positions is occupied by $\mathrm{Fe}^{3+}$. The relative dimensions of the tetrahedral and octahedral sheets allow an undistorted T-O-T packing, with an almost zero tetrahedral rotation angle $\alpha$ ( $\alpha$ in annite was calculated as $1.6^{\circ}$, Hazen and Burnham 1973). There is a very small difference between the means for six "inner" and six "outer" Cs-O distances, making the coordination of Cs 12 -fold, very close to an ideal hexagonal prism. A similar coordination was reported in the dioctahedral mica nanpingite- $2 \mathrm{M}_{2}$, a Cs analog of muscovite. However, it had a larger difference between "inner" and "outer" Cs-O distances of $\Delta \mathrm{Cs}-\mathrm{O}$ $=0.239 \AA$ and $\alpha=5.5^{\circ}(\mathrm{Ni}$ and Hughes 1996).

\section{High- $P$ results}

The variation of lattice parameters of "Cs-tetra-ferriannite" with pressure (Table 4) is shown in Figure 1, normalized to values corresponding to 1 bar. The compressional pattern is strongly anisotropic. The effects of pressure are most evident on the $c$ axis. Linear compressibility coefficients parallel to unit-cell edges are $\beta_{\mathrm{a}}=$ $1.6(2) \times 10^{-4}, \beta_{\mathrm{b}}=1.7(1) \times 10^{-4}, \beta_{\mathrm{c}}=14.0(5) \times 10^{-4}$ $\operatorname{kbar}^{-1}\left(\beta_{\mathrm{a}}: \beta_{\mathrm{b}}: \beta_{\mathrm{c}}=1: 1.1: 8.8\right)$; the $\beta$ angle increases linearly with pressure. Lattice parameters behave similarly in phlogopite where $\beta_{\mathrm{a}}=2.5 \times 10^{-4}, \beta_{\mathrm{b}}=2.8 \times 10^{-4}$, and $\beta_{\mathrm{c}}=11.7 \times 10^{-4} \mathrm{kbar}^{-1}$ (Hazen and Finger 1978), although the anisotropy of axial compressibilities is less pronounced $\left(\beta_{\mathrm{a}}: \beta_{\mathrm{b}}: \beta_{\mathrm{c}}=1: 1.1: 4.8\right)$. The difference is due to greater compressibility of the octahedral sheet of phlogopite wherein $\mathrm{MgO}_{6}$ is less rigid than $\mathrm{FeO}_{6}$ (as shown by comparative studies of Zhang et al. 1997 on clinopyroxenes). Differences also arise because of a

TABLE 7. Interatomic distances $(\AA)$ and geometric parameters in Cs-tetra-ferri-annite

\begin{tabular}{|c|c|c|c|c|c|c|}
\hline $\begin{array}{c}P \text { (kbar) } \\
T\left({ }^{\circ} \mathrm{C}\right)\end{array}$ & $\begin{array}{c}0.001 \\
23^{*}\end{array}$ & $\begin{array}{c}39.4 \\
23^{*}\end{array}$ & $\begin{array}{c}0.001 \\
23 \dagger\end{array}$ & $\begin{array}{l}0.001 \\
296 \dagger\end{array}$ & $\begin{array}{l}0.001 \\
435 \dagger\end{array}$ & $\begin{array}{c}0.001 \\
23 \ddagger\end{array}$ \\
\hline \multicolumn{7}{|c|}{ Tetrahedron } \\
\hline T-O1 & $1.688(3)$ & $1.66(2)$ & $1.686(1)$ & $1.684(3)$ & $1.684(6)$ & $1.679(2)$ \\
\hline $\mathrm{T}-\mathrm{O} 2 \mathrm{a}$ & $1.692(6)$ & $1.66(2)$ & $1.681(3)$ & $1.669(6)$ & $1.672(6)$ & $1.678(4)$ \\
\hline $\mathrm{T}-\mathrm{O} 2 \mathrm{~b}$ & $1.693(7)$ & $1.68(2)$ & $1.685(3)$ & $1.698(6)$ & $1.693(3)$ & $1.675(4)$ \\
\hline $\mathrm{T}-\mathrm{O} 3$ & $1.679(5)$ & $1.69(3)$ & $1.685(2)$ & $1.690(5)$ & $1.689(5)$ & $1.695(3)$ \\
\hline$\langle\mathrm{T}-\mathrm{O}\rangle$ & 1.688 & 1.67 & 1.684 & 1.685 & 1.685 & 1.682 \\
\hline Volume $\left(\AA^{3}\right)$ & $2.47(2)$ & $2.40(9)$ & $2.45(1)$ & $2.46(2)$ & $2.45(2)$ & $2.44(2)$ \\
\hline Tetrahedral tilt $\Delta z(\AA)$ & 0.013 & 0.04 & 0.006 & 0.016 & 0.005 & 0.020 \\
\hline Tetrahedral thickness $(\AA)$ & $2.272(3)$ & $2.24(1)$ & $2.279(2)$ & $2.265(3)$ & $2.263(3)$ & $2.273(2)$ \\
\hline Tetrahedral rotation $\alpha\left({ }^{\circ}\right)$ & 0.15 & 0.36 & -0.06 & -0.14 & -0.47 & 0.66 \\
\hline $\mathrm{M} 1-\mathrm{O} 3 \times 4$ & $2.139(5)$ & $2.11(2)$ & $2.135(2)$ & $2.141(5)$ & $2144(5)$ & 2169 (3) \\
\hline $\mathrm{M} 1-\mathrm{O} 4 \times 2$ & $2.117(5)$ & $2.11(2)$ & $2.113(3)$ & $2.121(8)$ & $2.109(8)$ & $2.064(4)$ \\
\hline$\langle\mathrm{M} 1-\mathrm{O}\rangle$ & 2.132 & 2.11 & 2.128 & 2.134 & 2.132 & 2.134 \\
\hline Volume $\left(\AA^{3}\right)$ & $12.67(5)$ & $12.2(3)$ & $12.60(3)$ & $12.74(5)$ & $12.72(5)$ & $12.62(3)$ \\
\hline$e_{s}(\AA)$ & 2.847 & 2.81 & 2.842 & 2.858 & 2.862 & 2.826 \\
\hline$e_{u}(\AA)$ & 3.173 & 3.14 & 3.167 & 3.170 & 3.161 & 3.199 \\
\hline$\psi\left({ }^{\circ}\right)$ & 59.3 & 59.4 & 59.2 & 59.1 & 58.9 & 59.9 \\
\hline \multicolumn{7}{|c|}{ M2 octahedron } \\
\hline M2-O3a ×2 & $2.136(5)$ & $2.10(2)$ & $2.132(2)$ & $2.130(5)$ & $2.131(5)$ & $2.136(3)$ \\
\hline $\mathrm{M} 2-\mathrm{O} 3 \mathrm{~b} \times 2$ & $2.138(5)$ & $2.11(2)$ & $2.133(2)$ & $2.138(5)$ & $2.152(5)$ & $2.121(3)$ \\
\hline $\mathrm{M} 2-\mathrm{O} 4 \times 2$ & $2.111(5)$ & $2.12(2)$ & $2.115(2)$ & $2.124(5)$ & $2.122(5)$ & $2.038(3)$ \\
\hline$\langle\mathrm{M} 2-\mathrm{O}\rangle$ & 2.128 & 2.11 & 2.127 & 2.131 & 2.135 & 2.098 \\
\hline Volume $\left(\AA^{3}\right)$ & $12.61(9)$ & $12.2(3)$ & $12.58(5)$ & $12.68(9)$ & $12.76(9)$ & $12.06(5)$ \\
\hline$e_{s}(\AA)$ & 2.845 & 2.81 & 2.841 & 2.856 & 2.864 & 2.800 \\
\hline$e_{u}(\AA)$ & 3.166 & 3.14 & 3.165 & 3.163 & 3.167 & 3.126 \\
\hline$\psi\left({ }^{\circ}\right)$ & 59.2 & 59.5 & 59.2 & 59.0 & 58.9 & 59.4 \\
\hline$\delta\left({ }^{\circ}\right)$ & 0.14 & 0.04 & 0.05 & 0.15 & 0.11 & 0.76 \\
\hline Octahedral thickness $(\AA)$ & $2.180(3)$ & $2.14(1)$ & $2.176(2)$ & $2.196(3)$ & $2.205(3)$ & $2.140(3)$ \\
\hline
\end{tabular}


TABLE 8. Bond distances and geometric parameters involving the interlayer region in "Cs-tetra-ferri-annite"

\begin{tabular}{|c|c|c|c|c|c|c|}
\hline $\begin{array}{c}P \text { (kbar) } \\
T\left({ }^{\circ} \mathrm{C}\right)\end{array}$ & $\begin{array}{c}0.001 \\
23^{*}\end{array}$ & $\begin{array}{l}39.4 \\
23^{*}\end{array}$ & $\begin{array}{c}0.001 \\
23 \dagger\end{array}$ & $\begin{array}{l}0.001 \\
296 \dagger\end{array}$ & $\begin{array}{l}0.001 \\
435 \dagger\end{array}$ & $\begin{array}{c}0.001 \\
23 \ddagger\end{array}$ \\
\hline \multicolumn{7}{|c|}{ Distances (Å) } \\
\hline Cs-O1 ×2 & $3.361(9)$ & $3.21(3)$ & $3.367(4)$ & $3.385(9)$ & $3.397(9)$ & $3.343(6)$ \\
\hline Cs-O1a $\times 2$ & $3.379(9)$ & $3.24(4)$ & $3.371(4)$ & $3.386(9)$ & $3.408(9)$ & $3.371(6)$ \\
\hline Cs-O2 $\times 4$ & $3.358(7)$ & $3.20(3)$ & $3.373(3)$ & $3.393(6)$ & $3.396(6)$ & $3.323(4)$ \\
\hline Cs-O2a $\times 4$ & $3.369(6)$ & $3.22(2)$ & $3.374(3)$ & $3.400(6)$ & $3.408(6)$ & $3.355(4)$ \\
\hline$\left\langle\mathrm{Cs}^{[12]}-\mathrm{O}\right\rangle$ & 3.366 & 3.22 & 3.372 & 3.393 & 3.402 & 3.345 \\
\hline Volume $\mathrm{Cs}^{[12]}\left(\AA^{3}\right)$ & $76.5(6)$ & $66(3)$ & $76.8(3)$ & $78.1(5)$ & $78.9(5)$ & $75.4(3)$ \\
\hline Interlayer thickness $(\AA)$ & $3.899(3)$ & $3.42(1)$ & $3.928(1)$ & $3.999(3)$ & $4.032(3)$ & $3.874(2)$ \\
\hline
\end{tabular}

smaller compressibility of the interlayer of phlogopite, as the $\mathrm{K}$ polyhedron is less compressible than the Cs polyhedron. The isothermal bulk modulus of "Cs-tetra-ferriannite," calculated as the reciprocal of the mean compressibility of the unit-cell volume, is 530(10) kbar. Bulk modulus $\mathrm{K}_{0}$ and its $P$ derivative $\mathrm{K}_{0}{ }^{\prime}$, determined by fitting the unit-cell volumes to a third order Birch-Murnaghan equation of state, are $\mathrm{K}_{0}=257(8) \mathrm{kbar}$ and $\mathrm{K}_{0}{ }^{\prime}=21(2)$.

To understand how individual structural units contribute to the evolution of the "Cs-tetra-ferri-annite" structure with $P$, the results of the refinement at $0.001 \mathrm{kbar}$ were compared with those at $39.4 \mathrm{kbar}$ (Tables 7 and 8). The mean T-O bond length decreases from 1.688 to 1.67 $\AA$, and the tetrahedral volume drops from $2.47(2)$ to

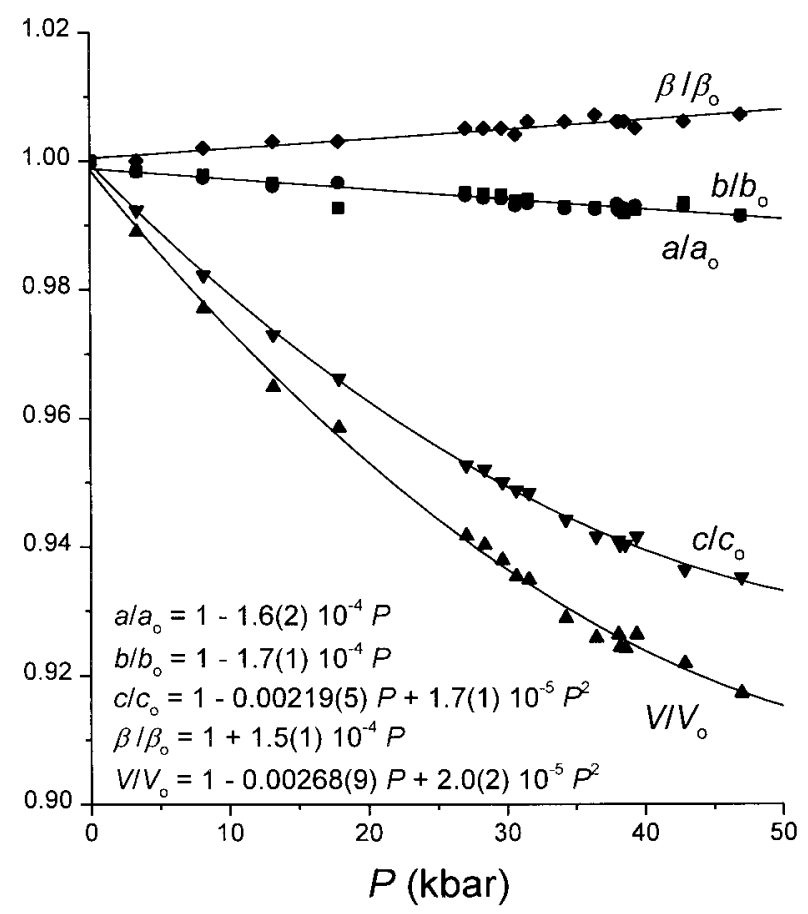

Figure 1. Variation of cell edges and volume, normalized to values at $1 \mathrm{bar}$, as a function of pressure. Squares $=a / a_{0}$; circles $=b / b_{0}$; downward-pointing triangles $=c / c_{0}$; upward-pointing triangles $=V / V_{0}$; diamonds $=\beta / \beta_{0}$.
2.40(9) $\AA^{3}$. The resulting polyhedral bulk modulus is 1370(400) kbar. Pressure seems to affect most the corrugation of the basal surface of tetrahedra $(\Delta z)$, by increasing it from 0.013 to $0.04 \AA$. To put this change into perspective, the highest values of $\Delta z$ known are those for muscovite $(0.20-0.23 \AA$ ), whereas in trioctahedral micas, they only exceptionally exceed $0.08 \AA(\Delta z=0.002 \AA$ in phlogopite, Hazen and Finger 1978; $0.008 \AA$ in tetraferriphlogopite, Donnay et al. 1964; $0.014 \AA$ in annite, Hazen and Burnham 1973). Somewhat more pronounced are the pressure-induced changes in the octahedral sheet. The structure remains homooctahedral, the mean M1-O and M2-O distances change from 2.132 and $2.128 \AA$ to 2.11 $\AA$ (the same in both). The volumes of octahedra drop from 12.67(5) and 12.61(9) $\AA^{3}$ to the value of 12.2(3) $\AA^{3}$ (both octahedra); octahedral bulk moduli are 1040(300) and 1190(300) kbar for M1 and M2, respectively. In the interlayer, the mean $\mathrm{Cs}-\mathrm{O}$ distance decreases from 3.366 to $3.22 \AA$. There is a small increase of the tetrahedral rotation angle $\alpha$ from $0.15^{\circ}$ to $0.36^{\circ}$. The $\mathrm{Cs}^{[12]}$ prism is very soft; its volume changes from $76.5(4)$ to $66(2) \AA^{3}$ with a polyhedral bulk modulus of 260(70) kbar. This value is among the lowest for oxygen-based polyhedra known to date.

The most conspicuous changes involve the interlayer where Cs is located: with increasing pressure, the interlayer thickness decreases from $3.899(3)$ to $3.42(1) \AA$, whereas the octahedral thickness drops from 2.180(3) to 2.14(1) $\AA$, and the tetrahedral thickness decreases from 2.272 (3) to 2.24(1) $\AA$. The contribution of the $2: 1$ layer to the thickness reduction along [001] is about five times less than that associated with the interlayer. The present results closely agree with those for phlogopite (Hazen and Finger 1978) where the contribution due to compression of the interlayer volume represents $75 \%$ of the overall reduction.

Comparing results for phlogopite and dioctahedral micas of the $\mathrm{K}-\mathrm{Na}$ series points to strong control of the interlayer cation over the mica compressibility. In Figure 2 , the bulk modulus correlates inversely with the ionic radius of the interlayer cation.

\section{High- $T$ results}

The variation of lattice parameters of "Cs-tetra-ferriannite" with temperature in the range $23-582{ }^{\circ} \mathrm{C}$ (Table 


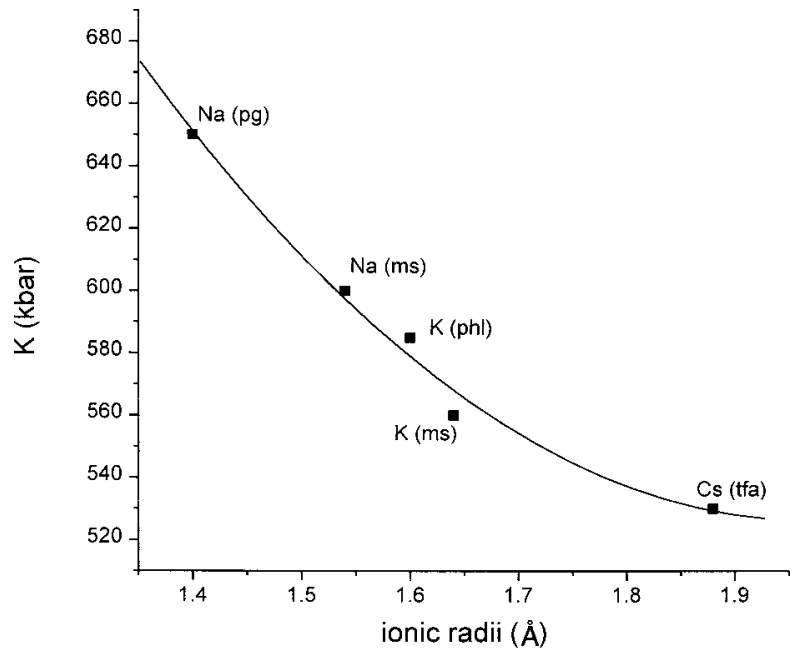

Figure 2. Bulk modulus of some micas vs. the ionic radius of the interlayer cation (radii from Shannon 1976). $\mathrm{Na}(\mathrm{pg})=$ paragonite with $\mathrm{K}_{\mathrm{T}}=650 \mathrm{kbar}$ (Comodi and Zanazzi 1997), $\mathrm{Na}(\mathrm{ms})=$ Na-rich muscovite with $\mathrm{K}_{\mathrm{T}}=600 \mathrm{kbar}$ (recalculated from Comodi and Zanazzi 1997), $\mathrm{K}(\mathrm{phl})=$ phlogopite with $\mathrm{K}_{\mathrm{T}}$ $=585 \mathrm{kbar}$ (Hazen and Finger 1978), K(ms) = muscovite with $\mathrm{K}_{\mathrm{T}}=560 \mathrm{kbar}$ (recalculated from Comodi and Zanazzi 1995), $\mathrm{Cs}(\mathrm{tfa})=$ "Cs-tetra-ferri-annite" with $\mathrm{K}_{\mathrm{T}}=530 \mathrm{kbar}$ (this work).

5) is shown in Figure 3, normalized to values corresponding to $23{ }^{\circ} \mathrm{C}$. The thermal expansion pattern is strongly anisotropic. Whereas $a$ and $b$ lattice parameters remain essentially unchanged throughout the temperature range, the thermal expansion coefficient of the $\mathbf{c}$ axis is $\alpha_{\mathbf{c}}=3.12(9)$ $\times 10^{-5}{ }^{\circ} \mathrm{C}^{-1}$ and the $\beta$ angle decreases linearly with temperature. These results are in a rough agreement with those reported for synthetic fluorphlogopite (Takeda and Morosin 1975) whose expansivities measured in the same $T$ range are $\alpha_{\mathrm{a}}=8.9 \times 10^{-6}, \alpha_{\mathrm{b}}=7.7 \times 10^{-6}, \alpha_{\mathrm{c}}=18$ $\times 10^{-6}{ }^{\circ} \mathrm{C}^{-1}\left(\alpha_{\mathrm{a}}: \alpha_{\mathrm{b}}: \alpha_{\mathrm{c}}=1.2: 1: 2.3\right)$. In fluorphlogopite, the expansivity along $\mathbf{c}$ direction is about one-half that in "Cs-tetra-ferri-annite." As in the high-pressure behavior, such pronounced differences can be ascribed to the very different T-O-T and interlayer composition of the two micas.

The structural refinements based on data measured at 296 and $435{ }^{\circ} \mathrm{C}$ (Tables 7 and 8) show that the larger thermal expansion along the $\mathbf{c}$ direction is mainly due to the dilatation of the interlayer. Over the interval between 23 and $435{ }^{\circ} \mathrm{C}$, the tetrahedral thickness barely changes, the octahedral thickness increases by $0.03 \AA$, but the interlayer separation increases by $0.10 \AA$. Mean M1-O and M2-O distances increase to $2.134 \AA$, less than $0.4 \%$, while the octahedral flattening angle $\psi$ decreases from 59.2 to $58.9^{\circ}$. The T-O distance remains constant over this $T$ range. All Cs-O bond lengths expand, although not homogeneously: bonds Cs-O1 and Cs-O1a are shortest at $23{ }^{\circ} \mathrm{C}$, but the shortest at $435{ }^{\circ} \mathrm{C}$ are $\mathrm{Cs}-\mathrm{O} 2$ and $\mathrm{Cs}-\mathrm{O} 1$. The rotation angle $\alpha$ changes from -0.06 to $-0.47^{\circ}$.

Above $450{ }^{\circ} \mathrm{C}$, "Cs-tetra-ferri-annite" underwent irre-

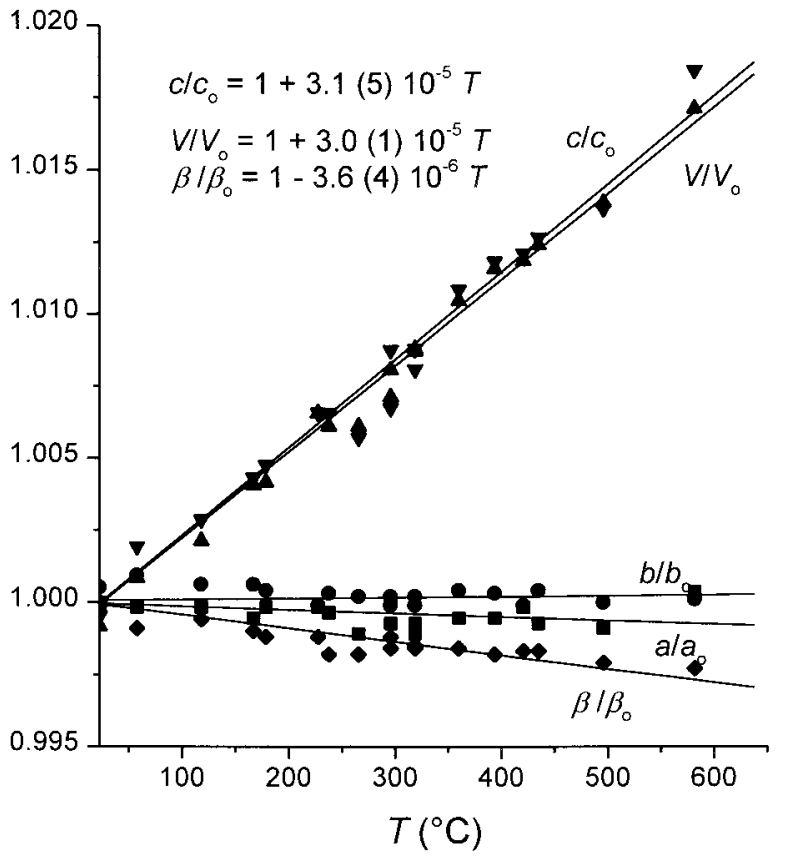

Figure 3. Lattice parameters of "Cs-tetra-ferri-annite" at various temperatures, normalized to values at $23{ }^{\circ} \mathrm{C}$. Symbols as in Fig. 1.

versible changes, the nature of which could be deduced from the refinement of the structure of crystal no. 2 at 23 ${ }^{\circ} \mathrm{C}$ after heating and from the change of unit-cell parameters at $582{ }^{\circ} \mathrm{C}$ measured as a function of time (up to $\sim 50$ h).

The refinement at $23{ }^{\circ} \mathrm{C}$ after heating does not indicate any significant changes in the tetrahedra. The volume of octahedron M1trans remains approximately the same as before the heating, while the M1-O mean distance increases slightly, in spite of the shortening of M1-O4 (i.e., M1-OH) bond lengths. Unlike M1, the M2cis octahedron contracts with a volume decrease of $0.5 \AA^{3}$ and a shortening of some M2-O distances, chiefly those involving $\mathrm{OH}^{-}$(Table 7). The $\psi$ flattening angle increases slightly for M1 and to a lesser extent for M2. Tetrahedral rotation angle $\alpha$ increases considerably to $0.66^{\circ}$. The mean Cs-O distance decreases and so does the volume of the Cs polyhedron (Table 8). These data suggest that the oxidation of $\mathrm{Fe}^{2+}$ takes place mainly in the M2 site, confirming the findings of Rancourt et al. (1994) for annite and the general crystal-chemical behavior of high-charge cations in trioctahedral micas (Cruciani and Zanazzi 1995). A complete oxidation of divalent iron in the M2 position, balanced by a loss of $\mathrm{H}_{2}$, can be described by the reaction $2 \mathrm{Fe}^{2+}+2 \mathrm{OH}^{-}=2 \mathrm{Fe}^{3+}+2 \mathrm{O}^{2-}+\mathrm{H}_{2}($ Dymek 1983).

The change of unit-cell parameters measured at regular time intervals on a crystal maintained at $582{ }^{\circ} \mathrm{C}$ in air (Fig. 4) follows two patterns, one for times up to $\sim 1800$ min and another for longer times. The inset in Figure 4 shows an exponential decrease of the cell volume vs. time during the first $1800 \mathrm{~min}$ and may represent a qualitative 


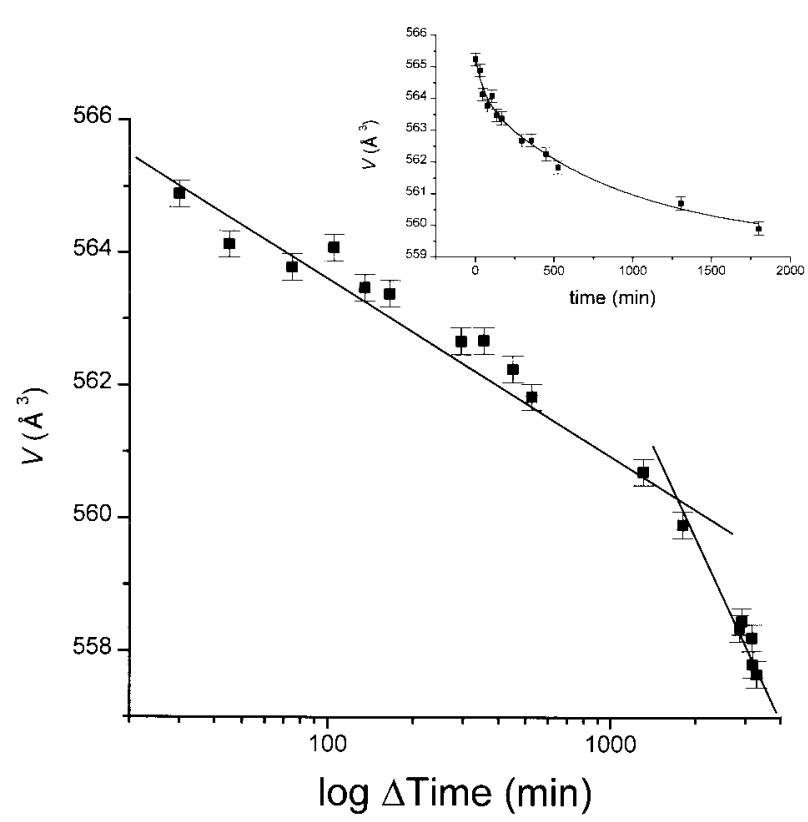

Figure 4. Unit-cell volume of "Cs-tetra-ferri-annite" as a function of time (in minutes) at $582{ }^{\circ} \mathrm{C}$.

kinetics of the above-mentioned oxidation-dehydroxilation of the mica at constant $T$. The steeper slope of the unit-cell volume decrease observed above $1800 \mathrm{~min}$ (Fig. 4) probably represents a different style of oxidation that involves $\mathrm{Fe}^{2+}$ in $\mathrm{M} 1$ and inflicts a further damage to the crystal structure, also betrayed by a decay of reflection intensities.

Obvious differences exist between trioctahedral and dioctahedral micas, so results from dehydroxylation of muscovite (Guggenheim et al. 1987) will not parallel those for "Cs-tetra-ferri-annite". In muscovite, the K-O2 bond length expands with temperature more rapidly than the other interlayer bonds, and the tetrahedral rotation angle $\alpha$ drops from 11.8 to $9.8^{\circ}$ as the temperature rises from 20 to $525{ }^{\circ} \mathrm{C}$. No analogous effects were observed in "Cs-tetra-ferri-annite".

\section{Discussion AND CONCLUSIONS}

The effects of pressure and temperature on the structure of "Cs-tetra-ferri-annite" are roughly similar, but opposite in sign. This applies to the changes in cell edges and their anisotropy, the behavior of the $\beta$ angle (which increases with $P$ and decreases with $T$ ) as well as polyhedral deformations (which behave antisymmetrically). The most evident effects concern the interlayer where the Cs cation with its large ionic radius is located. Cs is 12fold-coordinated, and the polyhedron-an almost ideal hexagonal prism - is a part of the structure with the highest compressibility or expansion coefficients, giving the framework the imprinting of a soft and dilatable array.

Other micas, such as phlogopite, also display the roughly "inverse" behavior with temperature and pressure, but the compressional and dilatation patterns of
"Cs-tetra-ferri-annite" are more anisotropic. Additionally, the anisotropic pattern of expansion and compression is quite different for both.

Independent isobaric data on thermal expansion and isothermal compressibility define the "geometric" equation of state for "Cs-tetra-ferri-annite" on the basis of cell-volume variations: $V / V_{0}=1+3.0(1) \times 10^{-5} T-$ $2.68(9) \times 10^{-3} P+2.0(2) \times 10^{-5} P^{2}$, where $T$ is in ${ }^{\circ} \mathrm{C}$, $P$ is in kbars. The $\alpha / \beta$ ratio of about 12 bar $/{ }^{\circ} \mathrm{C}$ indicates that the cell volume of "Cs-tetra-ferri-annite" will remain unchanged under a geothermal gradient of $\sim 23{ }^{\circ} \mathrm{C} / \mathrm{km}$. This value is higher than the mean geothermal gradient, but it may become realistic if additional heat is supplied by nuclear reactions, as may be true in a radioactive waste repository. In an oxidizing atmosphere, above $450{ }^{\circ} \mathrm{C}$, $\mathrm{Fe}^{2+}$ in the M2cis site of "Cs-tetra-ferri-annite" changes to $\mathrm{Fe}^{3+}$, while $\mathrm{OH}^{-}$changes to $\mathrm{O}^{2-}$. Structural changes associated with this reaction affect merely the lateral dimensions of the octahedral sheet.

Structural data obtained during the present research show that neither high pressure nor high temperature create any detectable internal strain in the structure. The tetrahedral rotation angle $\alpha$ remains nearly zero throughout the $P$ and $T$ range at room conditions, $0.36^{\circ}$ at $39.4 \mathrm{kbar}$, and $-0.47^{\circ}$ at $435^{\circ} \mathrm{C}$. In summary, the structure of " Cstetra-ferri-annite" seems to withstand well moderate conditions of temperature and pressure, showing a fair mechanical stability. It may be a suitable candidate for the storage of large ions (Cs) in its interlayer, also at high- $P$ and high- $T$ conditions, and should be considered as a potential component of Synroc.

\section{ACKNOWLEDGMENTS}

We thank Marcello Mellini for his interest and for providing the samples of "Cs-tetra-ferri-annite." This work was supported by CNR and MURST (project "Relations between structure and properties in minerals: analysis and applications") grants to P.F.Z. and by grant no. 205/96/0274 from Czech Grant Agency. International cooperation was possible due to the NATO Linkage Grant DISRM.LG 931421.

\section{REFERENCES CITED}

Comodi, P. and Zanazzi, P.F. (1993a) Improved calibration curve for the $\mathrm{Sm}^{2+}: \mathrm{BaFCl}$ pressure sensor. Journal of Applied Crystallography, 26, $843-845$.

- (1993b) Structural study of ellenbergerite. Part I: Effect of high temperature. European Journal of Mineralogy, 5, 819-829.

(1995) High-pressure structural study of muscovite. Physics and Chemistry of Minerals, 22, 170-177.

(1997) Pressure dependence of structural parameters of paragonite. Physics and Chemistry of Minerals, 24, 274-280.

Comodi, P., Melacci, P.T., Polidori, G., and Zanazzi, P.F. (1994) Trattamento del profilo di diffrazione da campioni in cella ad alta pressione. Proceedings of XXIV National Congress of Associazione Italiana di Cristallografia. Pavia, 27-29 September, 119-120.

Cruciani, G. and Zanazzi, P.F. (1994) Cation partitioning and substitution mechanism in $1 \mathrm{M}$ phlogopite: a crystal chemical study. American Mineralogist, 79, 289-301.

Denner, W., Schultz, H., and D'Amour, H. (1978) A new measuring procedure for data collection with a high-pressure cell on an X-ray fourcircle diffractometer. Journal of Applied Crystallography, 11, 260-264.

Donnay, G., Morimoto, N., Takeda, H., and Donnay, J.D.H. (1964) Trioctahedral one-layer micas. I. Crystal structure of a synthetic iron mica. Acta Crystallographica, 17, 1369-1373. 
Drábek, M., Rieder, M., Viti, C., Weiss, Z., and Frýda, J. (1998) Hydrothermal synthesis of a Cs ferruginous trioctahedral mica. Canadian Mineralogist (in press).

Ďurovič, S. (1981) OD-Charakter, Polytypie und Identifikation von Schichtsilikaten. Fortschritte der Mineralogie, 59, 191-226.

Dymek, R.F. (1983) Titanium, aluminium, and interlayer cation substitution in biotite from high-grade gneisses, West Greenland. American Mineralogist, 68, 880-899.

Finger, L.W. and King, H. (1978) A revised method of operation of the single-crystal diamond cell and refinement of the structure of $\mathrm{NaCl}$ at 32 kbar. American Mineralogist, 63, 337-342.

Guggenheim, S., Chang, Y.H., and Koster van Groos, A.F. (1987) Muscovite dehydroxylation: high-temperature studies. American Mineralogist, 72, 537-550.

Hazen, R.M. and Burnham, C.W. (1973) The crystal structure of one layer phlogopite and annite. American Mineralogist, 58, 889-900.

Hazen, R.M. and Finger, L.W. (1978) The crystal structures and compressibilities of layer minerals at high pressure. II. Phlogopite and Chlorite. American Mineralogist, 63, 293-296. York.

Ibers, J.A. and Hamilton, W.C., Eds. (1974) International Tables for Xray Crystallography, vol. 4, 99-101. Kynoch, Birmingham, U.K.

Lewis, J.B. (1985) Radioactive wastes: an overview. Mineralogical Magazine, 49, 153-158.

Mellini, M., Weiss, Z., Rieder, M., and Drábek, M. (1996) Cs-ferriannite as a possible host for waste cesium: crystal structure and synthesis. European Journal of Mineralogy, 8, 1265-1271.

Ni, Y. and Hughes, J.M. (1996) The crystal structure of nanpingite-2M the Cs end-member of muscovite. American Mineralogist, 81, 105-110.
North, A.C.T., Phillips, D.C., and Matthews, F.S. (1968) A semiempirical method of absorption correction. Acta Crystallographica, A24, 351359.

Pathak, P.D. and Vasavada, N.G. (1970) Thermal expansion of $\mathrm{NaCl}, \mathrm{KCl}$ and $\mathrm{CsBr}$ by $\mathrm{X}$-ray diffraction and the law of corresponding states. Acta Crystallographica, A26, 655-658.

Rancourt, D.G., Christie, I.A.D., Royer, M., Kodama, H., Robert, J.L., Lalonde, A.E., and Murad, E. (1994) Determination of accurate ${ }^{[4]} \mathrm{Fe}^{3+}$ ${ }^{\left[{ }_{6}\right.} \mathrm{Fe}^{3+}$, and ${ }^{[6]} \mathrm{Fe}^{2+}$ site populations in synthetic annite by Mössbauer spectroscopy. American Mineralogist, 79, 51-62.

Ringwood, A.E. (1985) Disposal of high-level nuclear wastes: a geological perspective. Mineralogical Magazine, 49, 159-176.

Shannon, R.D. (1976) Revised effective ionic radii and systematic studies of interatomic distances in halides and chalcogenides. Acta Crystallographica, A32, 751-767.

Sheldrick, G.M. (1993) SHELX-93. Program for crystal structure determination. University of Göttingen, Germany.

Takeda, H. and Morosin, B. (1975) Comparison of observed and predicted structural parameters of mica at high temperature. Acta Crystallographica, B31, 2444-2452.

Weiss, Z., Rieder, M., Chmielová, M., and Krajícek, J. (1985) Geometry of the octahedral coordination in micas: a review of refined structures. American Mineralogist 70, 747-757.

Zhang, L., Ahsbahs, H., Hafner, S.S., and Kutoglu, A. (1977) Singlecrystal compression and crystal structure of clinopyroxene up to 10 GPa. American Mineralogist, 82, 245-258.

Manuscript Received May 11, 1998

MANUSCRIPT ACCEPTED OCTOBER 5, 1998

PaPer handled by Nancy Ross 